\title{
Evaluation of Pyrite in a Tailings Dam by Flotation
}

\author{
Adnan Ceylan ${ }^{1}$, Gülay Bulut ${ }^{2}$ and Ferihan Göktepe ${ }^{3}$ \\ 1. Head Engineer, Park Electric Production Mining and Industry, Madenköy, Siirt, Turkey \\ 2. Istanbul Technical University, Maslak, Istanbul, Turkey \\ 3. Balikesir University, Balıkesir, Turkey
}

Received: December 30, 2012 / Accepted: February 01, 2013 / Published: April 25, 2014.

\begin{abstract}
Pyrite is presented as a gangue mineral in most of complex sulphide ores and most of time it is removed as a tailing. However, beneficiation of pyrite from tailings could be important because of its economical value and the environmental concern. This paper presents a research for the enrichment of pyrite from copper plant tailings, Siirt-Madenköy/Turkey, by flotation. Siirt-Madenköy copper mine is operated by Park Electric Production Mining and Industry since 2005. In order to obtain the pyrite from Siirt-Madenköy copper plant tailings, laboratory test work has to be done to determine the type of reagents, the flowsheet and the size of plant. The objective of the company is to develop a pyrite flotation circuit for concentration of pyrite from tailing dam to obtain 750,000 tons/year pyrite concentrate. There are about 4 million tons tailings that containing pyrite in the tailings dam. Experiments were carried out with three different types of tailings from the plant and the pyrite concentrate with $46 \% \mathrm{Fe}$ and $90 \%$ recovery has been obtained. Therefore, this study shows that high grade pyrite with high recovery can be recovered from the tailings.
\end{abstract}

Key words: Flotation, copper plant, chalcopyrite, pyrite, collectors.

\section{Introduction}

Head pyrite, naturally occurring iron disulfide- $\mathrm{FeS}_{2}$, is the most common sulfide in the earth's crust. It occurs in quartz veins, sedimentry or metamorphic rocks associated usually with other sulfides or oxides. It may contain significiant guantities of "penalty" elements, such as As, and generally constitutes the main gangue part of complex sulfide ores. It also presents in coal reserves as a major source of sulfur. Then, it is essential to rejected pyrite during milling processes from sulfide ores to reduce its contamination of the valuable mineral concentrate and to minimize the rate of penalty elements in concentrate, and from coal to reduce $\mathrm{SO}_{2}$ emission into air. On the other hand, it may be recovered as a source $\mathrm{S}$ for sulfuric acid production if the pyrite grade of ore is sufficient. Also, in some instances, pyrite is concentrated to gain valuable metals $(\mathrm{Ag}, \mathrm{Au})$

\footnotetext{
Coorreesponding author: Adnan Ceylan, head engineer, research field: flotation. E-mail: adnanceylan1@hotmail.com.tr.
}

associated with [1-5].

Pyrite flotation has been investigated by many researchers. These works revealed out that pyrite displays variable behaviour in flotation circuits. This behavior mainly related with origin and mineralogical composition of ore. Liberation size, electrochemical behavior of minerals constituting ore, the trace and minor element content of the mineral, texture, application variables belonging to flotation circuits determine the pyrite recovery in froth $[1,4,6,7]$. Pyrite is a chemically active mineral and can easily be oxidized. Therefore, zeta potential of pyrite changes depending on the surface state:isoelectric point of unoxidized pyrite is about at $\mathrm{pH} 2$. However, it was measured at about $\mathrm{pH} 6.4$ in various research works ant attributed to oxidation [8].

Xanthate is the most commonly employed collecting agent in sulfide flotation. It reverses the positive surface charge of pyrite in acid $\mathrm{pH}$ pulps, and gets it more negative at neutral and alkaline $\mathrm{pHs}$ with increasing the xanthate concentration $[4,8-10]$. There 
is a general consensus that xanthate makes pyrite hydrophobic adsorbing as dixanthogen and, meanwhile, the loss of positive charge associated with surface ferric hydroxide on the surface resulting in the negative increase in the zeta potential of pyrite. Some authors have also proposed that various ferric xanthate compounds might be formed under the condition of pyrite flotation. Xanthate has been proposed to adsorb on pyrite chemically in acid pulp condition as adsorbed xanthate and dixanthogen, and as ferric-xanthates at high concentration of iron ions. On the other hand, the adsorption has been attributed to the physical adsorption of aqueous dixanthogen and xanthate ions in alkaline pHs [4, 7-9, 11].

Pyrite is a somiconducting mineral. Among the sulfide minerals, it is the most nobel one and shows the highest rest potential. Therefore, in an aqueous environment, it exhibits the better catalysis property for oxygen reduction and for hydrogen evolution [12-15].

Flotation of copper sulphides such as chalcopyrite, bornite and covellite may easily be achieved using sulphydryl type collectors. In simple copper ores the valuable mineral chalcopyrite is generally associated with pyrite and silicate minerals. In the flotation of such ores chalcopyrite is generally floated using a selective collector depressing pyrite. The rougher concentrate is then cleaned several stages to produce the final concentrate. Pyrite, if desired, is floated at acidic $\mathrm{pH}$ conditions and silicates are discarded. The type and dosage of pyrite depressants chosen is very much related to the pyrite/chalcopyrite ratio $[13,14]$. However, in the case of complex ores where different types of sulphide minerals exist or very fine grinding is required, seperation becomes very difficult. Chalcopyrite could be associated with other valuable sulphides of zinc and lead or with pyrite being the gangue mineral. In all cases, selective separation of chalcopyrite is essential and may generally present difficulties [16].

The separation of valuable minerals from gangue minerals in flotation is ruled by complex reactions and interaction betwen water, minerals, air bubbles and reagents. Water is extremely important in the separation of minerals as it controls mineral hydrophobicity and because of the large amount of water used in the flotation circuit.

Temperature can affect the sulphide mineral surface chemistry with changes in minerals oxidation state, dissolution rate and precipitation of species from solution. Temperature can also affect the effectiveness of chemical reagents such as collectors, depressants or frothers, which can result in reduced flotation performance and higher reagent consumption [17]. Therefore, temperature of the water can also affect the flotation behaviour of minerals. There are only a few studies in the literature which deal with the effect of temperature on mineral flotation [18-19]. Anecdotal evidences in various plants around the world suggest that seasonal change in temperature has an influence on flotation performance. For example, at the Garpenberg flotation plant (Boliden) in Sweden, zinc recovery fluctates between summer and winter months [20].

The success of flotation depends both on the ore characteristics and the flotation process applied. In flotation it is important to use mineral selective collectors, however, in the case of deactivation the use of mineral selective depressants is of up most importance, even the type of $\mathrm{pH}$ modifiers could determine the efficiency of flotation. Depressants such as cyanide, lime, sodium meta bi-sulphite are very effective in the deactivation of pyrite yet chalcopyrite might be depressed to some extend [13, 14]. Chalcopyrite is known to exhibit inherent floatability yet thiol collectors are always used in the industrial applications for the separation of complex sulfide ores by flotation. In a complex sulfide ore flotation, the recovery of a particular sulfide mineral is usually affected by the choice of surface modifying agents and the collector [21]. The choice of collectors can be made on the basis of the mineralogy of the ore, 
metallurgical objectives, and the operating conditions. In simple copper ores the valuable mineral chalcopyrite is generally assocated with pyrite and silicate minerals. In the flotation of such ores chalcopyrite is generally floated using a selective collector depressing pyrite. Depressants such as cyanide, lime, sodium meta bi-sulfide are very effective in the deactitivation of pyrite yet chalcopyrite might be depressed to some extend [13, 14, 22].

In pyrite flotation adsorbed oxygen and iron (III) have been excluded as possible oxidation agents. The oxidation products of the disulphide ion in pyrite e.g., $\mathrm{S}_{2} \mathrm{O}_{7}-2$ and $\mathrm{S}_{2} \mathrm{O}_{8}-2$ are proposed to be responsible for the oxidation of xanthate ions to dixanthogen [23] which is the species responsible for flotation when xanthate is added as collector [8, 15, 24, 25].

The separation of minerals based on preferential wetting of their surface is one of the most ambitious technological applications of physical chemistry. The mechanisms of foam flotation of sulfide and nonsulfide minerals are essentially different. Sulfide minerals are characterized by the presence of variable-valent ions and the electrochemical mechanism of collector sorption leading to the critical importance of pulp redox potential for flotation. The interaction of mineral with collector depends on the electrochemical potential of mineral surface; therefore, in general, the flotation is observed in the limited potential range. This potential depends on a variety of anodic processes and the only cathodic reaction, namely, oxygen reduction [26].

In the Siirt-Madenköy, about 30 million tons ore with $2 \% \mathrm{Cu}$ grade is fed to the plant and the copper concentrate with $20 \% \mathrm{Cu}$ grade and $87 \%$ recovery is produced at the end of the flotation process. Aerophine 3,418 A, MIBC, sodium silicate and lime are used as flotation reagents. Pyrite is discharged as a tailing with silicate minerals. In Fig. 1, tailing with pyrite dam and in Fig. 2, the flowsheet of copper plant is given.

Tailings from sulfide mines usually contain large amount of pyrite $\left(\mathrm{FeS}_{2}\right)$ which is the main source of acid rock drainage. Pyrite waste must be disposed off under strictly controlled conditions. Large areas of land, on the other hand, contain alkali soils not suitable for any kinds of agricultural production. This type of soils can be remedied by lowering the $\mathrm{pH}$ and exchangeable sodium percentage (ESP) of the soil using certain agents. Because of its acid generating capacity, pyrite may be a viable alternative for such soils [6].

Pyrite easily oxidizes to form sulphuric acid. Removing the pyrite prior to discharging the tailings will decrease the potential for acid generation from tailings and minimize possible waste treatment and remediation costs. In this study, possibility ofrecovering pyrite from copper plant tailing was investigated.

The usage of dextrin at different $\mathrm{pH}$ values does not have an important effect on the flotation. The starch is more effective than dextrin for depressing sulphide minerals. The results indicated that the higher $\mathrm{pH}$ the higher grade of concentrate is with organic polymers. Copper content increases as a result the depression of pyrite at high $\mathrm{pH}$ values by $\mathrm{OH}^{-}$ions [27, 28].

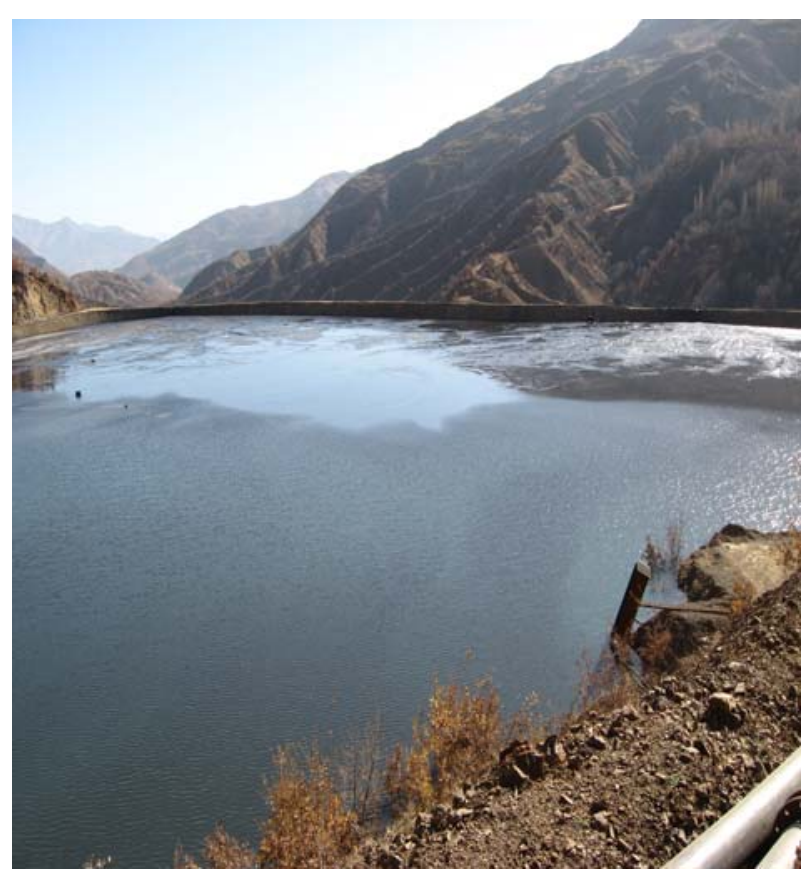

Fig. 1 Tailing with pyrite dam. 


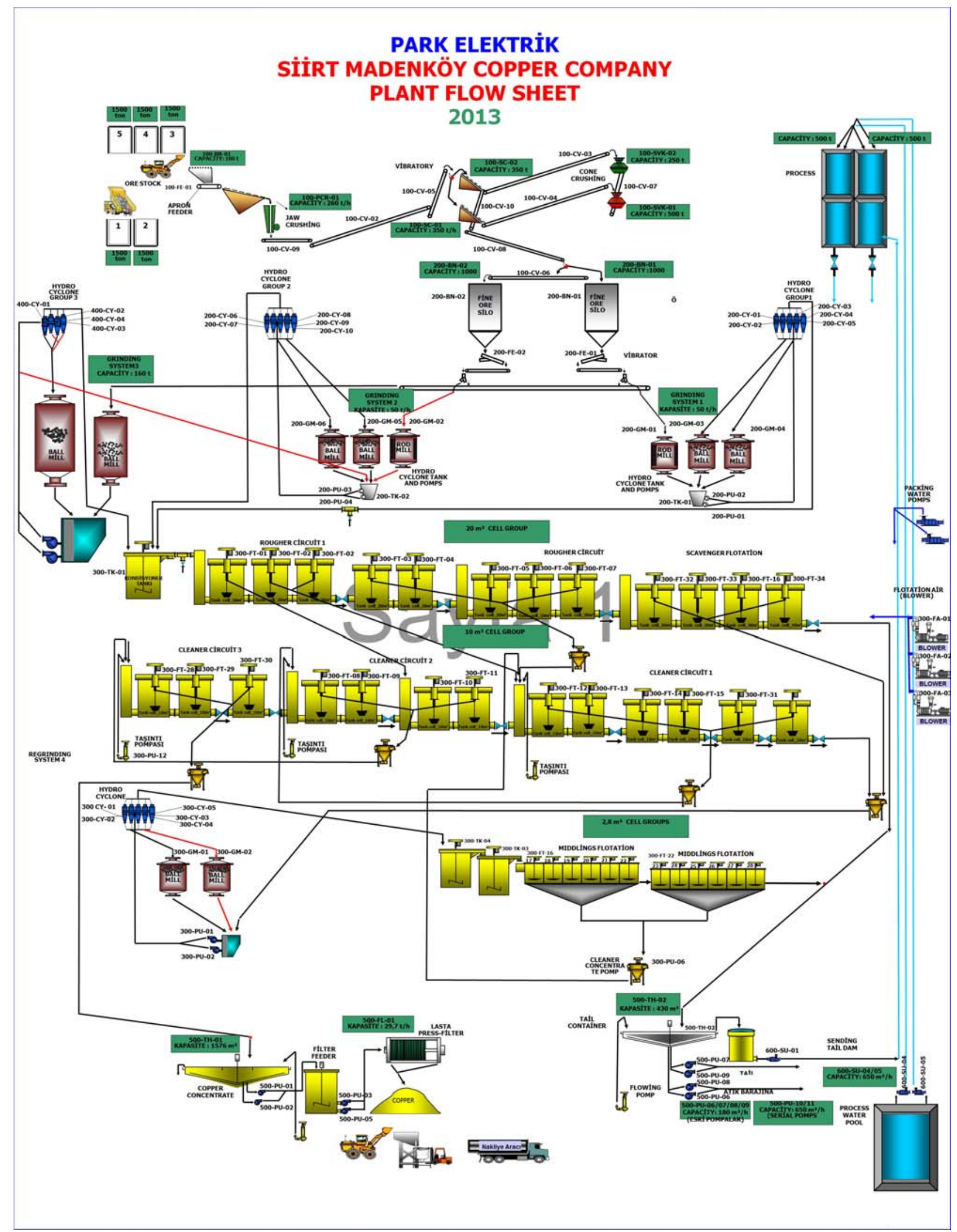

Fig. 2 Siirt-Madenköy copper plant flow-sheet. 


\section{Materials and Methods}

\subsection{Materials}

The capacity of the plant is about $1,200,000$ tons/year and it is assumed to reach 100,000 tons copper concentrate per year. The goal of the plant is to increase capacity to about $15,000,000$ tons in a year by increasing capacity it is assumed to reach 120,000 tons copper concentrate in a year. For that purpose, it was ordered a new grinding mill and a new cells. It is expected that new equipments will decrease the particle size of ore and flotation process will yield better selectivity and recovery. According to the mineralogical analyses, the ore sample contains chalcopyrite $\left(\mathrm{CuFeS}_{2}\right)$, sphalerite $(\mathrm{ZnS})$, pyrite $\left(\mathrm{FeS}_{2}\right)$, galena ( $\mathrm{PbS})$, hematite $\left(\mathrm{Fe}_{2} \mathrm{O}_{3}\right)$, limonite $\left(\mathrm{FeO}(\mathrm{OH}) \cdot \mathrm{nH}_{2} \mathrm{O}\right)$, calcite $\left(\mathrm{CaCO}_{3}\right)$ and quartz $\left(\mathrm{SiO}_{2}\right)$. Chalcopyrite phases locked with cataclastic pyrite structure and chalcopyrite was seen to fill in the fractures of pyrite as a matrix material as well as it showed a colloidal structure with pyrite. Furthermore chalcopyrite particles of between 5 and $70 \mu \mathrm{m}$ were seen to scatter in gangue minerals. On the other hand sphalerite was observed to have a locked structure with chalcopyrite and inclusions within chalcopyrite where average phase size was $30 \mu \mathrm{m}$ and pyrite average phase size $75 \mu \mathrm{m}$.
The sample for flotation tests was taken from Siirt-Madenköy Copper Mine waste in South-East of Turkey. Three types of tailings were used. Chemical analysis of the tailing samples are shown in Table1. This table shows that rested tailing has about 2\% higher $\mathrm{Fe}$ content but lower $\mathrm{Cu}$ content than the others and $\mathrm{Zn}$ and $\mathrm{Pb}$ contents are almost the same for each type of tailing samples.

Table 2 shows the size distribution of samples. This shows that about $55 \%$ dry and rested tailings are between $-0.149+0.074 \mathrm{~mm}$, but for wet sample only $33 \%$ is in this fraction and $38 \%$ is below $0.025 \mathrm{~mm}$. Fig. 3 shows the size distribution that wet tailing shows completely different slope while the other samples show almost the same slope.

\subsection{Methods}

Flotation is a process effected from numerous parameters such as $\mathrm{pH}$, reagent type and dosages etc. In the literature, there are many studies including the optimum parameters for flotation of pyrite.Therefore in this study only the effect of $\mathrm{pH}$ and grinding were investigated in detail.

Flotation tests were conducted employing a 2.5 liter Denver flotation cells. The flowsheet of method is given in Fig. 4. Sample was floated and pyrite is collected at the first stage and the tailing of this stage

Table 1 Chemical analysis of tailings.

\begin{tabular}{llll}
\hline SAMPLE & $\% \mathrm{Cu}$ & $\% \mathrm{Fe}$ & $\% \mathrm{Zn}$ \\
\hline Rested tailing & 0.14 & 33.29 & 0.32 \\
Dry tailing & 0.22 & 30.96 & 0.27 \\
Wet tailing & 0.18 & 29.91 & 0.31 \\
\hline
\end{tabular}

Table 2 Size distribution of flotation sample.

\begin{tabular}{|c|c|c|c|c|c|c|}
\hline \multirow[b]{2}{*}{$\begin{array}{l}\text { Particle size } \\
(\mathrm{mm})\end{array}$} & \multicolumn{2}{|c|}{ Dry tailing } & \multicolumn{2}{|c|}{ Rested tailing } & \multicolumn{2}{|c|}{ Wet tailing } \\
\hline & $\begin{array}{l}\text { Weight } \\
(\%)\end{array}$ & $\begin{array}{l}\text { Accumulated pass } \\
\text { through }(\%)\end{array}$ & $\begin{array}{l}\text { Weight } \\
(\%)\end{array}$ & $\begin{array}{l}\text { Accumulated } \\
\text { pass through \% }\end{array}$ & $\begin{array}{l}\text { Weight } \\
(\%)\end{array}$ & $\begin{array}{l}\text { Accumulated } \\
\text { pass through } \%\end{array}$ \\
\hline$-0.149+0.074$ & 54.94 & 100.0 & 53.18 & 100.0 & 33.15 & 100.0 \\
\hline$-0.074+0.044$ & 22.3 & 45.06 & 22.7 & 46.82 & 15.56 & 66.85 \\
\hline$-0.044+0.025$ & 11.41 & 22.76 & 12.37 & 24.12 & 13.37 & 51.29 \\
\hline-0.025 & 11.35 & 11.35 & 11.75 & 11.75 & 37.92 & 37.92 \\
\hline Total & 100.0 & - & 100.0 & - & 100.0 & - \\
\hline
\end{tabular}




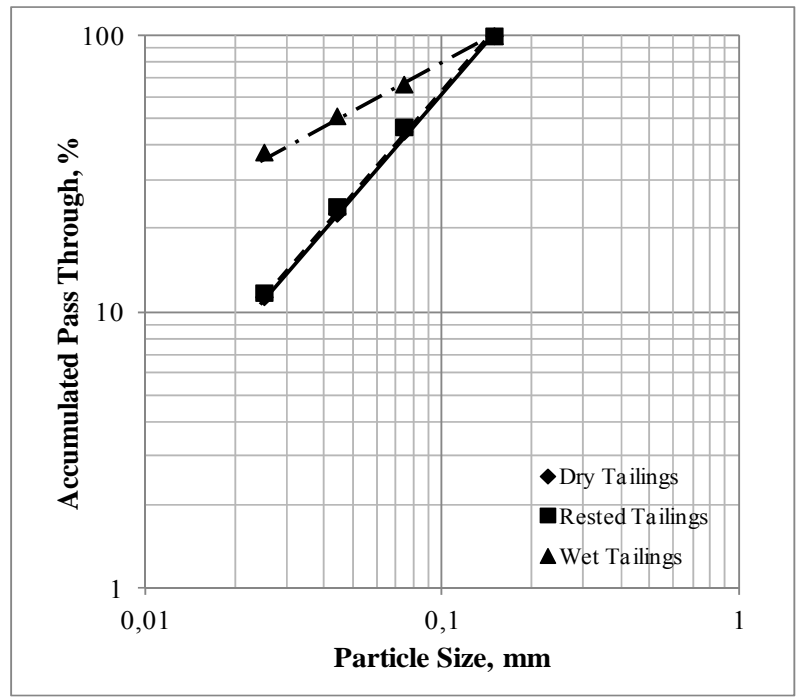

Fig. 3 Size distribution of samples.

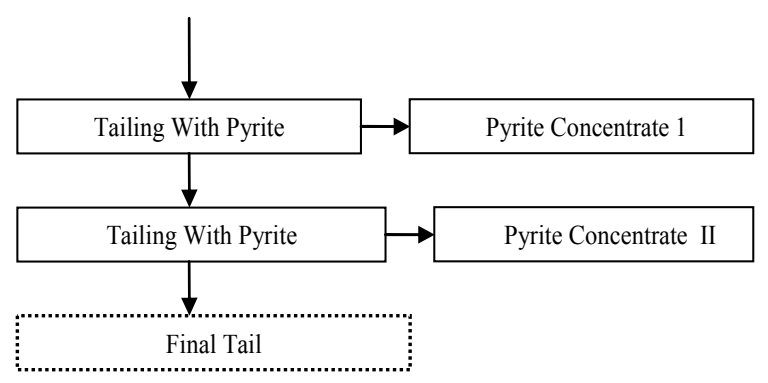

Fig. 4 The flowsheet of flotation tests.

floated again as a scavenger stage, final tail and second pyrite concentrate was obtained as flotation product.

In the flotation tests, Potassium Amyl Xanthate (PAX) at $160 \mathrm{~g} /$ ton dosage is used as collector, as well as MIBC at $23 \mathrm{~g} /$ ton as frother were used. The effect of PAX concentrate, $\mathrm{pH}$ and effect of grinding was investigated.

To determine the flotation characteristics of Siirt-Madenköy ore sample, pre experiments were carried out in Istanbul Technical University Mineral Processing Engineering Department. It was aimed to depress zinc, pyrite, silicate minerals and produce a copper concentrate with high grade and recovery. The use of a lime in the flotation circuits is practically universal in the flotation of copper ores. High $\mathrm{pH}$ values depress the iron sulphide gangue minerals which are commonly associated. Therefore, the effect of $\mathrm{pH}$ was investigated at high alkaline values of 11.5 and 12.1. The results indicated pyrite was depressed more at $\mathrm{pH} 12.1$ than $\mathrm{pH}$ 11.5. After that; all the experiment were carried out around pH 12 [29].

\section{Results and Discussion}

Flotation is affected by numerous factors as $\mathrm{pH}$, feed size, temperature, various reagent types including collectors, depressors, activators and etc. In most of the literature, the optimum conditions for pyrite flotation was given in detail. However, At the beginning, flotation test were carried out with above reagents without $\mathrm{pH}$ adjustment, at natural $\mathrm{pH}$ that was $7.58,7.75$ and 8.01 for wet tailing, rested tailing and dry tailing respectively. Results given in Table 3 shows that concentrates with about $42 \%-46 \% \mathrm{Fe}$ grade with about $70 \%-75 \%$ recovery were obtained at the first stage of flotation. At scavenger stage about $10 \%$ can be recovered with lower grade $(32 \%-35 \%)$ as expected. As pure pyrite contains $46.7 \% \mathrm{Fe}$, results should be improved. Then flotation tests.

\subsection{Effect of $p H$}

At the beginning, flotation test were carried out with above reagents without $\mathrm{pH}$ adjustment, at natural $\mathrm{pH}$ that was $7.58,7.75$ and 8.01 for wet tailing, rested tailing and dry tailing respectively. Results are given in Table 3 shows that concentrates with about $42 \%-46 \% \mathrm{Fe}$ grade with about $70 \%-75 \%$ recovery were obtained at the first stage of flotation. At scavenger stage about $10 \%$ can be recovered with lower grade (32\%-35\%) as expected. As pure pyrite contains $46.7 \% \mathrm{Fe}$, results should be improved. Then flotation tests for three types of sample with the same reagent were repeated at $\mathrm{pH} 4$. The results in Table 4 indicate that best pyrite grade and recovery were obtained with the Rested tailing at $\mathrm{pH} 4$ with $90 \%$ recovery and $46 \% \mathrm{Fe}$.

Experiments were carried out with the same were conditions and only $\mathrm{pH}$ was changed to 6 . Results demonstrated at Table 5 which shows that again better 
Table 3 The Flotation results of tailings at natural $\mathrm{pH}$.

\begin{tabular}{llccc}
\hline & Products & Weight (\%) & Content & Recovery \\
\cline { 4 - 5 } & & 50.34 & 41.90 & 68.41 \\
Wet tailing & Concentrate1 & 7.67 & 35.75 & 8.9 \\
pH: 7.58 & Concentrate2 & 41.99 & 16.67 & 22.69 \\
& Tailing & 100.0 & 30.83 & 100.0 \\
\hline & Total & 60.30 & 45.80 & 70.18 \\
Rested tailing & Concentrate1 & 13.82 & 31.70 & 11.14 \\
pH: 7.75 & Concentrate2 & 25.88 & 28.43 & 18.68 \\
& Tailing & 100.0 & 39.35 & 100.0 \\
\hline & Total & 50.98 & 43.09 & 74.14 \\
Dry tailing & Concentrate1 & 8.50 & 33.45 & 9.6 \\
pH: 8.01 & Concentrate2 & 40.52 & 11.90 & 16.26 \\
& Tailing & 100.0 & 29.63 & 100.0 \\
\hline
\end{tabular}

Table 4 The flotation results of tailings at pH 4.

\begin{tabular}{|c|c|c|c|c|}
\hline & \multirow{2}{*}{ Products } & \multirow{2}{*}{ Weight (\%) } & \multicolumn{2}{|c|}{$\mathrm{Fe}(\%)$} \\
\hline & & & Content & Recovery \\
\hline \multirow{4}{*}{ Wet tailing } & Concentrate 1 & 56.61 & 44.7 & 74.44 \\
\hline & Concentrate 2 & 6.44 & 30.71 & 5.82 \\
\hline & Tailing & 36.95 & 18.15 & 19.74 \\
\hline & Total & 100.0 & 33.99 & 100.0 \\
\hline \multirow{4}{*}{ Rested tailing } & Concentrate 1 & 80.86 & 46.1 & 89.88 \\
\hline & Concentrate 2 & 2.97 & 33.29 & 2.39 \\
\hline & Tailing & 16.17 & 19.84 & 7.73 \\
\hline & Total & 100.0 & 41.47 & 100.0 \\
\hline \multirow{4}{*}{ Dry tailing } & Concentrate 1 & 57.24 & 43.02 & 81.67 \\
\hline & Concentrate 2 & 5.27 & 20.23 & 3.54 \\
\hline & Tailing & 37.49 & 11.9 & 14.79 \\
\hline & Total & 100.0 & 29.63 & 100.0 \\
\hline
\end{tabular}

Table 5 The flotation results tailings at pH 6.

\begin{tabular}{llccc}
\hline & Products & Weight (\%) & Content & Recovery \\
\cline { 3 - 4 } Wet tailing & & 52.16 & 43.84 & 70.08 \\
& Concentrate 1 & 9.31 & 32.05 & 9.15 \\
& Concentrate 2 & 38.53 & 17.6 & 20.77 \\
& Tailing & 100.0 & 32.63 & 100.0 \\
\hline \multirow{3}{*}{ Rested tailing } & Total & 64.88 & 45.76 & 85.88 \\
& Concentrate 1 & 2.95 & 29.02 & 2.48 \\
& Concentrate 2 & 32.17 & 12.52 & 11.64 \\
& Tailing & 100.0 & 34.57 & 100.0 \\
\hline \multirow{3}{*}{ Dry tailing } & Total & 69.53 & 43.68 & 81.96 \\
& Concentrate 1 & 9.02 & 27.30 & 6.65 \\
& Concentrate 2 & 21.45 & 19.69 & 11.39 \\
\hline
\end{tabular}




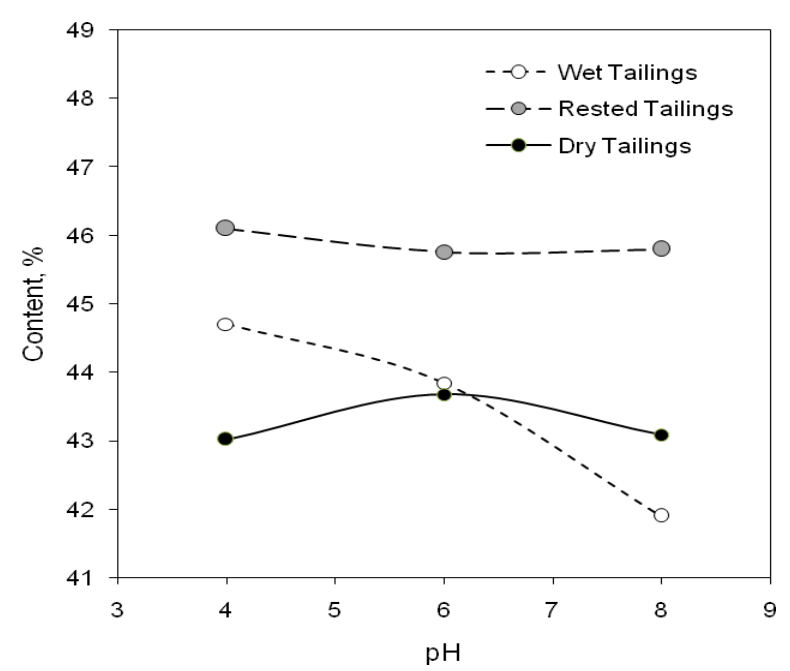

Fig. 5 The effect of $\mathrm{pH}$ on content.

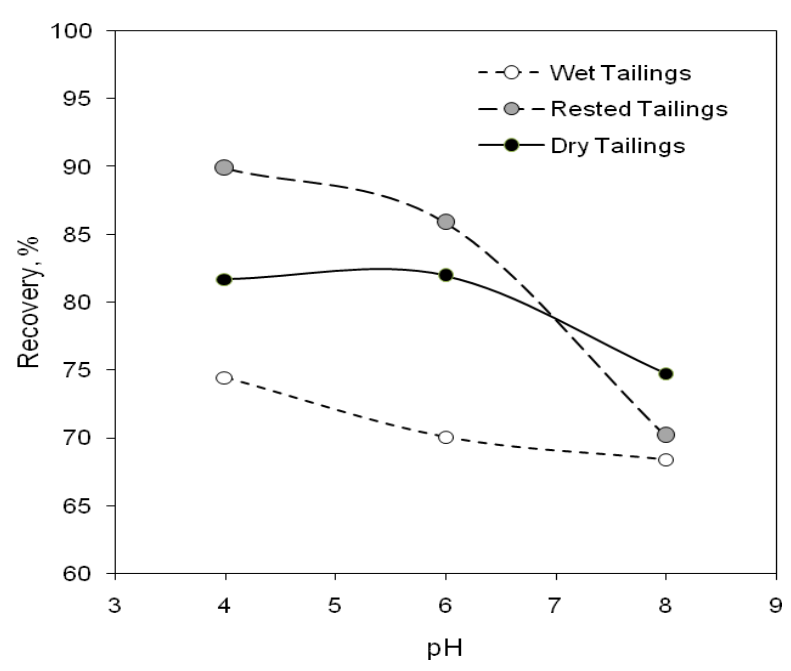

Fig. 6 The effect of $\mathrm{pH}$ on recovery. results were obtained with Rested sample (46\% recovery with $45.8 \% \mathrm{Fe}$ ) but this is not better than $\mathrm{pH} 4$.

Figs. 5 and 6 summarizes the all results for grade and recovery respectively. Natural $\mathrm{pH}$ was 7.5-8 and in the graphs they have been shown as $\mathrm{pH}$. As expected pyrite floats better at acidic conditions. When three types of tailings were compared better results were obtained with rested sample for all $\mathrm{pHs}$.

\subsection{Effect of Grinding}

10 min grinding was applied to the all three samples to compare the results with previous study and $\mathrm{pH}$ was adjusted 4 and 6 . The results are given in Table 6 at $\mathrm{pH}$ 6. This shows that grinding did not improve the results for wet and rested tailings almost same recovery and grade were obtained with previous study as given in Tables 4 and 5 only with dry sample, 5\% higher recovery was obtained. Table 7 shows the results for flotation at $\mathrm{pH} 4$ after 10 minutes grinding was applied but again this did not improve the grade and recovery for all three type of tailings.

\section{Conclusions}

Siirt-Madenköy copper ore flotation tail contains mainly pyrite. To reduce the amount of tail in the damp and to recover the pyrite as a saleable product

Table 6 The flotation results at pH 6 (10 minutes grinding time).

\begin{tabular}{llccc}
\hline \multirow{2}{*}{ Wet tailing } & Peight(\%) & \multicolumn{2}{c}{$\mathrm{Fe}(\%)$} \\
\cline { 3 - 4 } & Concentrate1 & 56.22 & Content & 73.90 \\
& Concentrate2 & 7.63 & 41.82 & 6.94 \\
& Tailing & 36.15 & 28.91 & 19.16 \\
\hline \multirow{3}{*}{ Rested tailing } & Total & 100.0 & 16.87 & 100.0 \\
& Concentrate1 & 79.00 & 31.81 & 87.82 \\
& Concentrate2 & 3.65 & 44.26 & 3.21 \\
& Tailing & 17.35 & 34.94 & 8.97 \\
Dry tailing & Total & 100.0 & 20.60 & 100.0 \\
& Concentrate1 & 65.59 & 39.81 & 86.84 \\
& Concentrate2 & 3.72 & 40.88 & 2.09 \\
& Tailing & 30.69 & 17.32 & 11.07 \\
\hline
\end{tabular}


Table 7 The flotation results at pH 4 (10 min grinding time).

\begin{tabular}{llccc}
\hline & Products & Weight(\%) & Content & Recovery \\
\cline { 3 - 4 } Wet tailing & Concentrate1 & 53.92 & 34.46 & 64.58 \\
& Concentrate2 & 7.85 & 33.47 & 9.13 \\
& Tailing & 38.23 & 19.78 & 26.29 \\
& Total & 100.0 & 28.77 & 100.0 \\
\hline \multirow{3}{*}{ Rested tailing } & Concentrate1 & 80.64 & 46.66 & 88.93 \\
& Concentrate2 & 4.57 & 34.30 & 3.70 \\
& Tailing & 14.79 & 21.04 & 7.37 \\
& Total & 100.0 & 42.30 & 100.0 \\
\hline \multirow{3}{*}{ Dry tailing } & Concentrate1 & 58.24 & 42.13 & 83.49 \\
& Concentrate2 & 6.04 & 20.23 & 4.15 \\
& Tailing & 35.72 & 10.16 & 12.36 \\
\hline
\end{tabular}

wet, dry and rested tails were studied. Flotation was performed at natural $\mathrm{pH}, \mathrm{pH} 4$ and $\mathrm{pH}$ 6. As expected better flotation results were obtained at low $\mathrm{pH}$, especially with Rested tailing, the concentrate with $46.1 \%$ Fe and with $90 \%$ recovery was obtained. As pure pyrite contains $46.70 \% \mathrm{Fe}$ this is certainly acceptable result. Applying grinding did not improve the results which shows that there is no liberation problem.

The results showed that, as it was the main objective, pyrite flotation will provide benefits for both financially and environmentally.

\section{References}

[1] P.K. Abraitis, R.A.D. Pattrick, D.J. Vaughan, Variations in the compositional, textural and electrical properties of natural pyrite: A review, İnternational Journal of Mineral Processing 74 (2004) 41-59.

[2] T. Albrecht, D. Fornasiero, Flotation of sphalerite: Effect of copper concentration and temperature, in: 22nd World Mınıng Congress, İstanbul Turkey, 2011, pp. 409-416.

[3] T. Güler, S. Çetinkaya, Ü. Akdemir, T. Doğan, D. Kocabağ, Effect of fe-ions on pyrite-xanthate interaction in chemically manipulated electrochemical conditions, International Journal of Natural Engineering and Sciences 3 (3) (2009) 1-7.

[4] C.L. Jiang, X.H. Wang, B.K. Parekh, J.W. Leonard, The surface and solution chemistry of pyrite flotation with xanthate in the presence of iron ions, Colloids and Surfaces A: Physicochemical Engineering Aspects 136 (1998) 51-62.

[5] D. Kocabağ, T. Güler, Two-Liquid flotation of sulphides:
An elecrochemical approach, Minerals Engineering 20 (2007) 1246-1254.

[6] G. Aydın, A.İ. Arol, G. Çaycı, Remediation of alkali solis with waste pyrite, in: 22 nd World Minıng Congress, İstanbul Turkey, 2011, pp. 357-361.

[7] N.K. Mendiratta, Kinetic studies of sulfide mineral oxidation and xanthate adsorption, Ph.D. Thesis, Virginia Polytechnic Institute, Blaclsburg, VA, 2000.

[8] M.C. Fuerstenau, M.C. Kuhn, D.A. Elgillani, The role of dixanthogen in xanthate flotation of pyrite, AIME, Society of Mining Eng. Transactions 241 (1968) 148-156.

[9] G. Bulut, F. Arslan, S. Atak, Flotation behaviors of pyrites with different chemical compositions, Minerals and Metallurgical Processing 21 (2004) 86-92.

[10] A.L. Valdivieso, A.A.S. Lopez, S. Song, On the cathodic reaction coupled with the oxidation of xanthates at the pyrite, aqueous solution interface, International Journal of Mineral Processing 77 (2005) 154-164.

[11] Z. Ekmekçi, Role of galvanic interaction on the collectorless flotation of chalcopyrite-pyrite, Ph.D. Thesis, Hacettepe University, Ankara, Turkey, 1995. (In Turkish)

[12] T. Biegler, D.A.J. Rand, R. Woods, Oxygen Reduction on Sulphide Minerals, Trends in Elecrohemistry, Plenum Press, New York, 1977.

[13] A. Gül, A.A. Sirkeci, S. Sahin, The effect of various depressants on the selective flotation of murgul copper ore, in: Proceedings of 24th International Mineral Processing Congress, Beijing China, 2008, pp. 1210-1214.

[14] A. Gül, A.E. Yüce, A.A. Sirkeci, M. Özer, Use of non-toxic depressants in the selective flotation of copper lead-zinc ores, Canadian Metallurgical Quarterily 47 (2) (2008) 111-118.

[15] R. Woods, Electrochemistry of Sulphide Flotation, Floation, AIME, New York, 1976, Vol. 1,

[16] A. Gül, The Role of $\mathrm{Na}_{2} \mathrm{~S}_{2} \mathrm{O}_{5}$ and activated carbon on the 
selective flotation of chalcopyrite from a copper ore using a dithiophosphine-type collector, Mineral Processing Extractive Metal. Rev. 28 (2007) 235-245.

[17] T. Albrecht, D. Fornasiero, Flotation of sphalerite:effect of copper concentration and temperature, in: 22nd World Mınıng Congress, İstanbul Turkey, 2011, pp. 409-416.

[18] I.J. Lin, The effect of seasonal variations in temperature on the performance of mineral processing plants, Minerals Engineering 2 (1989) 47-54.

[19] C.T. O'Conner, P.J.T. Mills, The effect of temperature on the pulp and froth phases in the flotation of pyrite, Minerals Engineering 3 (6) (1990) 615-624.

[20] AMIRA P260E, Impact of recycled and low guality process water on sustainable mineral beneficiation practices, Final report, June 2010, pp. 11-49.

[21] S. Chander, A. Khan, Effect of sulfur dioxide on flotation of chalcopyrite, International Journal of Mineral Processing 58 (1-4) (2000) 45-55.

[22] S.M. Bulatoviç, Handbook of Flotation Reagents Chemistry, Theory and Practice: Flotation of Sulfide Ores, Elseiver Science \& Technology, 2007.

[23] I. Persson, P. Persson, M. Valli, S. Fozu, B. Malmenstan, Reaction on sulphide mineral surfaces in connection with xanthate flotation studied by diffuse reflectance FTIR spectroscopy, atomic adsorption spectrophotometry and calorimetry, International Journal of Mineral Processing 33 (1991) 67-81.

[24] A.M. Marabini, M. Barbaro, V. Alesse, New reagents in sulphide mineral flotation, International Journal of Mineral Processing 33 (1991) 291-306.

[25] X. Wang, K.S.E. Forssberg, Mechanism of pyrite flotation with xanthates, International Journal of Mineral Processing 33 (1991) 275-290.

[26] V.E. Vigdergauz, Oxidation catalysis in mineral flotation, 14th Balkan Mineral Processing Congress, Tuzla, Bosnia \& Herzegovinal, 2011, pp. 260-262.

[27] A. Ceylan, G. Bulut, Improvement of Siirt-Madenköy Copper Plant Performance, in: 22 nd World Mining Congress, İstanbul Turkey, 2011, pp. 375-382.

[28] A. Ceylan, G. Bulut, Inorganic and organic depressants effect on the flotation of a copper ore, in: 14th Balkan Mineral Processing Congress, Tuzla, Bosnia \& Herzegovinal, 2011, 144-148.

[29] A. Ceylan, Concentration of the Siirt-Madenköy ores with flotation method, Master Thesis, Istanbul Technical University, 2009. 